\title{
Hubungan Penggunaan Media Sosial Whatsapp Berkonten Pornografi dengan Perilaku Seksual Berisiko pada Remaja di SMKN X Jakarta Timur
}

\author{
Nurwati Rettob $^{1}$, Murtiningsih ${ }^{2 *}$ \\ ${ }^{1,2}$ STIKes Jayakarta PKP DKI \\ Email:*murtiningsihkadun@gmail.com
}

Submitted : $12 / 10 / 2020$

Accepted: 11-01-2021

Published: $06 / 03 / 2021$

\begin{abstract}
WhatsApp is social media which very popular in the society. Using social media such as WhatsApp has a positives and negatives impacts. The negative impact of WhatsApp is the teenager which access and share the link of pornographies. The aim of this research is to know the relation between the users of WhatsApp as social media which has content of pornographies and sexual behaviors toward teenagers at SMKN X East Jakarta. The methodology in this research is using correlation study. The instrument which is using questionnaire of user WhatsApp as social media and questionnaire which for the people who has big risk to sexual behaviors. Population which uses in this research is students at SMKN X East Jakarta which took 104 respondents as sample. The result from univariate analyses in this research is showing us that most of the respondents which using WhatsApp as social media has 58 respondents $(55,8 \%)$ that got negative impacts. And for sexual behaviors 58 respondent $(55,8 \%)$ which categorize to have big risk. The result of analyses of chi square, that shows us that there is signification relation between the users of WhatsApp as social media which has content of pornographies and sexual behaviors towardteenagers at SMKN X East Jakarta with value p-value (0,040), and value OR=2,470 which means that if the users of social media such WhatsApp that has contents of pornographies (negative) then teenagers have big opportunity to do sexual behaviors.
\end{abstract}

Key World: whatsapp using, pornography, risk sexual behavior, teenagers.

\begin{abstract}
Abstrak
WhatsApp adalah media sosial yang paling populer di masyarakat. Penggunaan media sosialWhatsApp memiliki dampak positif dan negatif. Dampak negatif WhatsApppada remaja diantaranya adalah remajamengakses dan bertukar linkpornografi. Tujuan Penelitian ini untuk mengetahui hubungan penggunaan media sosial WhatsApp berkonten pornografidengan perilaku seksual berisiko pada remaja di SMKN X Jakarta Timur. Metode dalam penelitian ini menggunakan rancangan study korelasi. Instrumen yang digunakan adalah kuesioner penggunaan media sosial WhatsApp dan kuesioner perilaku seksual berisiko. Populasi pada penelitian ini adalah siswa/siswi SMKN X Jakarta Timur dengan sampel sebanyak 104 responden. Hasil analisa yang digunakan adalah chi square. Hasil Analisa univariat didapatkanpenggunaan media sosial WhatsApp negatif lebih banyak yaitu 58 responden $(55,8 \%)$ dan perilaku seksual dalam kategori beresiko sebanyak 58 responden $(55,8 \%)$. Hasil penelitian terdapat hubungan yang signifikan antara penggunaan media sosial WhatsApp berkonten pornografidengan perilaku seksual berisiko pada remaja di SMKN X Jakarta Timur dengan nilaip-value $(0,040)$, dan nilai $\mathrm{OR}=2,470$ yang menunjukan bahwa apabila pengunaan media sosial WhatsApp berkonten pornografi negatif maka remaja memiliki kesempatan untuk melakukan perilaku seksual berisiko.
\end{abstract}

Kata Kunci : penggunaan whatsapp, pornografi, perilaku seksual berisiko, remaja

\section{PENDAHILUAN}

Menurut

Word

Health

Organization(2011), pravelensi remaja di dunia diperkirakan 1,2 miliyar atau sekitar seperlima dari jumlah penduduk dunia 10-
19 tahun. Menurut Badan Kependudukan dan Keluarga Berencana Nasional BKKBN (2017), rentang usia remaja adalah 10-24 tahun dan belum menikah. Menurut Kemenkes RI (2015), jumlah kelompok usia 10-19 tahun di Indonesia menurut 
Sensus Penduduk 2010 sebanyak 43,5 juta atau sekitar $18 \%$ dari jumlah penduduk. Didunia diperkirakan kelompok remaja berjumlah 1 milyar atau $18 \%$ dari jumlah penduduk.

Pada masa remaja informasi tentang masalah seksual sudah berkembang pesat di internet, pada masa ini remaja memiliki rasa ingin tahu yang tinggi terhadap masalah seksual sehinga tidak dapat dipungkiri remaja menggunakan intenet untuk memenuhi rasa keingintahuan tentang setiap informasi yang diiginkannya (Yudrik Jahaja (2011)). Era globalisasi teknologi semakin maju, sehingga tidak dapat dipungkiri hadirnya internet semakin dibutuhkan dalam kehidupan sehari-hari, baik dalam kegiatan sosialisasi, pendidikan, tidak dapat dipungkiri bahwa media sosial mempunyai pengaruh yang besar dalam kehidupan masyarakat khususnya kalangan remaja, media sosial sudah menjadi candu yang membuat penggunanya tiada hari tanpa membuka media sosial.

Berdasarkan data dari We are Social \& Hootsuite (2019), Jumlah penggunaan internet di seluruh dunia diproyeksikan mencapai tiga miliyar jiwa pada tahun 2015, sedangkan pada tahun 2019 diperkirakan sebanyak 4,437 miliyar jiwa mengakses internet dari total 7,697 miliar jiwa populasi dunia. Berdasarkan data dari (Asosiasi Penyelenggara Jasa Internet Indonesia (APJII), 2018) pengguna internet di Indonesia selalu mengalami peningkatan setiap tahunnya, mencapai $64,8 \%$ atau sama dengan 171,17 juta jiwa dari total 264,16 juta jiwa populasi di Indonesia.

WhatsApp (WA)adalah apliksi yang dirancang untuk memudahkan penggunanya untuk tetap terhubung dan berkomunikasi kapan saja, dan dimana saja. WA memberikan berbagai macam fitur bagi penggunanya dengan menggratiskan pengiriman pesan dan melakukan panggilan secara sederhana, aman, dan cepat ke berbagai jenis telepon di seluruh penjuru dunia. Aplikasi media sosial WhatsApp dapat digunakan untuk mengirim dan menerima berbagai macam media dalam bentuk teks, foto, video, dokumen, dan lokasi, bahkan WhatsApp saat ini dapat digunakan untuk melakukan panggilan suara dan panggilan video. Pesan dan panggilan menggunakan WhatsApp dapat diamankan dengan enskripsi end-toend, sehingga tidak ada pihak ketiga, (Nasrullah, 2017).

Berdasarkan data Pernita Hestin Untari (2020), Di Amerika Serikat (AS), pengguna media sosial WhatsApp mencapai 68,1 juta. Jumlah pengguna WhatsApp terus meningkat di AS, diprediksi akan mencapai 85,8 juta pada 2023. Berdasarkan data dari survei (Hootsuite, 2019), WhatsApp menjadi salah satu media sosial paling aktif digunakan oleh masyarakat Indonesia mencapai $83 \%$. Artinya sekitar 124 pengguna internet,menggunakan WhatsApp pada gadg et mereka. WhatsApp menempati urutan kedua untuk media sosial paling aktif di Indonesia. pengguna WhatsApp meningkat karena lebih banyak orang mengandalkan aplikasi WA untuk tetap berhubungan dengan teman dan keluarga mereka.

Menurut penelitianDewi (2020), yang berjudul hubungan penggunaan smartphone dengan perilaku seksual bebas pada remaja di SMKX Gunung Putri Bogor didapatkan data sebanyak $94.6 \%$ responden pernah mengirim video porno digrup WhatsApp. Adapun remaja yang menyalahgunakan chatting menyimpang seperti chat seks serta mengirim video pornografi hasil penelitian ini sejalan dengan hasil wawancara yang dilakukan pada siswa di SMK " $X$ " tersebut bahwa adanya grup WhatsApp satu sekolah yang sengaja dibuat hanya untuk saling bertukar video pornografi didalamnya. Group WA tersebut dibuat khusus untuk saling bertukar atau mengirim video-video berbau pornografi. 
Menurut Azmiah Soebagijo(2010) pornografi merupakan tulisan atau gambar, suara, tampilan bergerak atau hal-hal yang membangkitkan gairah seksual. Teknologi yanng makin canggih membuat produk pornografi beraneka ragam, serta adanya kemudahan akses untuk mencapai sumbersuber dan bahan porno. Pornografi dalam 10 tahun terakhir memang berkembang luarbiasa pesat, terutama sejak di temukan internet abad 20. Saat ini hampir $70 \%$ situs pornografi yang tersedia di web berisi pornografi.

Komisi Perlindungan Anak Indonesia (KPAI) (2018), menyebutkan bahwa $96 \%$ anak-anak berusia 10-17 tahun di Indonesia pernah membuka konten negatif (porno) dengan rata-rata penggunaannya 64 jam setiap bulannya terhadap 4.500 pelajar SMP dan SMA di 12 kota besar. Remaja tersebut mengaku telah mengakses situs berkonten pornografi dan juga menonton video porno melalui internet. Ketika remaja mengakses konten negatif saat menggunakan internet, maka remaja tersebut rentan terhadap permasalahan perilaku seksual berisiko.

Pada remaja usia 15-19 tahun, proporsi terbesar bepacaran pertama kali pada usia 15-17 tahun sekitar 33,3\% remaja perempuan dan $34,5 \%$ remaja laki-laki yang berusia 15-19 tahun mulai berpacaran pada saat meraka belum berusia 15 tahun. Pada usia tersebut dikhawatirkan belum memiliki ketrampilan hidup (life skils) yang memadai,sehingga mereka berisiko memiliki perilaku pacaran yang tidak sehat,antara lain melakukan hubungan sekssual berisiko (Kemenkes RI , 2015). Hasil Survei Kesehatan Reproduksi Remaja Indonesia (SKRRI) (2011), remaja (14-19 tahun) tentang perilaku seksual berisiko remaja terhadap kesehatan reproduksi remaja menunjukkan dari 19.173 remaja 92\% sudah pernah berpacaran. Pada saat berpacaran melakukan pegang-pegangan tangan, $82 \%$ ciuman, $62 \%$ melakukan petting, dan 10,2\% melakukan hubungan seksual berisiko di Jabotabek.

Berdasarkan hasil study pendahuluan yang di lakukan oleh peneliti pada tanggal 17 desember 2019 dengan memberikan kuesioner sederhana kepada 15 siswa/siswi SMKN X Jakarta didapatkan remaja yang pernah mendapatkan situs video pornografi dari temanya yang dikirim melalui aplikasi WhatsApp sebanyak 5 orang $(33,3 \%)$, remaja yang sering mendapatkan situs video pornografi sebanyak 6 orang $(40 \%)$, remaja yang tidak mendapatkan situs video pornografi sebanyak 4 orang $(26,7 \%)$. Berdasarkan hasil diskusi yang dilakukan menggunakan metode FGD (Focus Group Discussion) kepada 15 remaja di dapatkan hasil bahwa terdapat 3 remaja yang mengatakan ada salah satu dari temannya sudah mencoba untuk menyebarkan video pornografi via WhatsApp di group mereka. Tujuan dari penelitian ini adalah untuk mengetahui hubungan penggunaan media sosial WhatsApp berkonten pornografi dengan perilaku seksual berisiko pada remaja di SMKN X Jakarta Timur.

\section{METODE PENELITIAN}

Metode penelitian ini menggunakan studi korelasi. Lokasi penelitian ini dilakukan di SMKN X Jakarta Timur Waktu penelitian pengumpulan data dalam penelitian ini sudah di lakukan pada tanggal 25 April 2020 sampai 6 Juni 2020.Populasi dalam penelitian ini sebanyak 125 responden. Jumlah sempel dalam penilitian ini adalah 104 responden SMKNX Jakarta Timur. Metode sampling yang digunakan dalam penelitian ini mengunakan metode kuota sampling yaitu sempel yang diambil berdasarkan kuota sempel yang dibutukan yaitu 104 responden. Pengumpulan data dilakukan pada saat pandemic Covid 19, sehingga peneliti tidak melakukan tatap muka langsung dengan responden. Pengambilan data melibatkan wali kelas untuk 
menyebarkan link kuesioner kepada siswa/siswi menggunakan google form, setelah kuesinoner disebarkan oleh wali kelas peneliti memantau melaluiemail goole form untuk mengetahui jumlah dari setiap responden yang sudah mengisi kuesioner, setelah jumlah kuota sampel terpenuhi 104 responden peneliti langsung memberitahukan kepada pihak sekolah bahwa penelitan sudah selesai dan bagi sisiwa/siswi yang belum mengisi kuesioner diberitahukan bahwa tidak perlu mengisi link kuesioner karena penelitian sudah selesai dan kuota menjadi responden sudah penuh. Analisa data menggunakan ChiSquare. Alat pengumpulan data pada penilitian ini adalah kuesioner.

\section{HASIL DAN PEMBAHASAN}

Tabel 1 Distribusi Frekuensi Responden Berdasarkan Usia Siswa SMKN X Jakarta Timur Tahun 2020 (N=104)

\begin{tabular}{ccc}
\hline Usia & Frekuensi & \% \\
\hline 16 Tahun & 27 & 25,0 \\
17 Tahun & 73 & 70,2 \\
18 Tahun & 4 & 4,8 \\
\hline Total & 104 & 100
\end{tabular}

Tabel 1 hasil analisis didapatkan bahwa reponden yang berusia 17 tahun lebih banyak yaitu 73 reponden $(70,2)$ dan reponden yang berusia 16 tahun sebanyak 27 responden $(26,0)$, dan responden yang berusia 18 tahun sebanyak 4 responden $(4,8)$.

Penelitian ini selaras dengan penelitian yang dilakukan oleh Wijayanti Nor (2019), terdapat responden mayoritas yang berusia 17 tahun sebanyak 64 orang $(56,15 \%)$. Hasil penelitian ini selaras dengan penelitian yang diteliti oleh (Pratama Dimas dkk, 2017), didapatkan hasil bahwa responden yang berusia 17 tahun sebanyak $54(60,7 \%)$. Penelitan ini juga berkaitan dengan teori Kumalsari dkk
(2014), karakteristik remaja yang berusia 17 mulai mengungkapkan kebebasan diri, mempunyai cirta tubuh (body image), dapat mewujudkan rasa cinta yang mendalam. Pada usia 17 tahun merupakan ambang masa dewasa dengan semakin mendekat nya usia kematangan, mereka mulai tertarik kepada lawan jenis dan mulai berpacaran.

Tabel 2 Distribusi Frekuensi Responden Berdasarkan Jenis Kelamin Siswa SMKN X Jakarta Timur Tahun 2020 (N=104)

\begin{tabular}{ccc}
\hline $\begin{array}{c}\text { Jenis } \\
\text { kelamin }\end{array}$ & Frekuensi & \% \\
\hline Laki-laki & 75 & 72,1 \\
Perempuan & 29 & 27,9 \\
\hline Total & 104 & 100
\end{tabular}

Tabel 2 menunjukkan bahwa reponden yang berjenis kelamin laki-laki lebih banyak yaitu 75 responden $(72,1 \%)$ dan responden yang berjenis kelamin perempuan sebanyak 29 responden $(27,9 \%)$.

Hasil penelitian ini selaras dengan penelitianYuli (2013), menunjukkan bahwa sebgaian besar responden berjenis kelamin laki-laki sebanyak 57 responden $(57,6 \%)$, sedangkan yang berjenis perempuan sebanyak 42 responden $(42,4 \%)$.Penelitian ini berkaitan dengan penelitiansebelumnya olehJonathan (2018), kebiasaan remaja mengakses pornografi sabanyak $93 \%$ lakilaki sudah terpapar konten pornografi dan remaja perempuan terpapar konten pornografi sebanyak $71 \%$. Hasil penelitian ini berkaitan dengan hasil survei Kemenkes (2015) presentase seks pra nikah pada remaja tahun 2012, remaja laki-laki lebih banyak pernah melakukan seks pranikah $14,6 \%$ dibandingkan perempuan $1,8 \%$. Dari hasil survei yang sama di dapatkan alasan hubungan seksual pranikah tersebut sebagian besar karena penasaran ingin tahu $(57,5 \%)$, terjadi begitu saja $(38 \%)$. 
Tabel 3 Distribusi Frekuensi Berdasarkan Kuesioner Penggunaan Media Sosial WhatsApp Di SMKN X Jakarta Timur Tahun 2020 (N=104)

\begin{tabular}{lll}
\hline Variabel & Frekeunsi & Presentasi \\
\hline Positif & 46 & $44,2 \%$ \\
Negatif & 58 & $55,8 \%$ \\
\hline Total & 104 & $100 \%$ \\
\hline
\end{tabular}

Tabel 3 menunjukkan hasil penelitian didapatkan hasil bahwa responden yang menggunakan media sosial WhatsApp secara positif sebanyak 46 responden $(44,2 \%)$, dan responden yang menggunakan media sosial WhatsApp secara negatif sebanyak 58 responden $(55,8 \%)$.

Hasil penilitian ini sejalan dengan penilitian Dewi (2020), didapatkan data bahwa sebanyak $94.6 \%$ responden pernah mengirim video porno digrup WhatsApp. Adapun remaja yang menyalahgunakan chatting menyimpang seperti chat seks serta mengirim video pornografi hasil penelitian ini sejalan dengan hasil wawancara yang dilakukan pada siswa di SMK " $X$ " tersebut bahwa adanya grup WhatsApp satu sekolah yang sengaja dibuat hanya untuk saling bertukar video pornografi didalamnya.

Menurut Azmiah Soebagijo, (2010) pornografi merupakan tulisan atau gambar, suara, tampilan bergerak atau hal-hal yang membangkitkan gairah seksual. Teknologi yanng makin canggih mebuat membuat produk pornografi beraneka ragam, serta adanya kemudahan akses untuk mencapai sumber-suber dan bahan porno. Pornografi dalam 10 tahun terakhir memang berkembang luar biasa pesat, terutama sejak ditemukan internet abad 20. Saat ini hampir $70 \%$ halaman situs pornografi yang tersedia di web berisi pornografi. Penilitian ini didukung oleh Komisi Perlindungan Anak
Indonesia (KPAI) (2018), yang menyatakan bahwa 96\% anak-anak berusia 10-17 tahun di Indonesia pernah membuka konten negatif (porno) dengan rata-rata penggunaannya 64 jam setiap bulannya terhadap 4.500 pelajar di 12 kota besar sebanyak $97 \%$ remaja mengaku telah mengakses situs berkonten pornografi dan juga menonton video porno melalui internet. Ketika remaja sudah terlibat dalam perilaku negatif ketika menggunakan internet, maka remaja tersebut rentan terhadap permasalahan perilaku seksual berisiko. Hasil penelitian ini sejalan dengan penelitian Harni Andriani dkk (2016), mengatakan bahwa remaja yang mengakses media pornografi lebih banyak yaitu 83 responden (92,2\%), dan sebanyak 7 responden $(7,8 \%)$ remaja tidak pernah mengakses konten pornografi. Penelitian ini selaras dengan penelitian yang diteliti oleh Pujiati Eny (2018), bahwa sebanyak 264 responden $(82,2 \%)$ sering terpapar media pornografi dan hanya 57 responden $(17,8 \%)$ yang jarang terpapar media pornografi. Ketertarikan remaja terhadap materi porno berkaitan dengan masa transisi yang sedang dialaminya serta adanya dorongan perilaku seksual tersebut dapat muncul ketertarikan dengan lawan jenis yang melibatkan emosi (rasa cinta,sayang) sehingga menimbulkan rangsangan remaja untuk melakukan.

Penelitian ini didukung oleh BKKBN (2017), Hasil survei pornografi yang dilakukan di DKI jakarta dan pandeglang menunjukkan sebanyak 96,7\% telah terpapar pornografi, dan $3,7 \%$ mengalami kecanduan pornografi. Penelitian ini selaras dengan penelitian Rahmawati (2012), mengatakan sebanyak $34,5 \%$ remaja SMA Kesatria Medan yang mengakses situs porno (cybersex) dan terjerumus dalam perilaku seksual berisiko. Dampak dari cybersex dapat merangsang hasrat seksual sehingga membuat individu langsung melakukan apa yang mereka lihat (acting out). 
Penelitian ini sejalan dengan penelitian yang diteliti Akbar (2017), banyak masalah yang disebabkan oleh paparan pornografi di internet data yang di peroleh sebanyak 32\% di kota-kota besar di Indonesia pernah berhubungan seks. Kota-kota besar yang dimaksud tersebut antara lain Jakarta, Surabaya, dan Bandung, dan dari data survey yang dilakukan diketahui bahwa salah satu pemicu utama dari perilaku remaja tersebut adalah muatan pornografi yang diakses via internet . Hasil penelitian ini berkaitan dengan penelitian Suwarni Linda (2015), menunjukan sebagian besar responden terpaparan media pornografi sebanyak (57,3\%). Kecanggihan teknologi yang semakin hari semakin cangih dapat berdampak buruk bagi remaja terutama remajaa yang sudah salah mengunakan media sosial mereka untuk mengakses konten pornografi, sesuai dengan teori Indriyani (2014), menjelaskan remaja adalah tahap umur yang datang setelah masa kanak-kanak berakhir, di tandai oleh pertumbuhan fisik yang cepat. Selain pertumbuhan fisik remaja juga mengalami perubahan emosional dan psikososial dikarenakan kematangan organ-organ seksual dan perubahan hormonal, mengakibatkan terjadinya perilaku seksual beresiko. Dorongan seksual remaja menimbulkan rasa keingin tahuan akan seksualitas serta remaja berani mengabil resiko.

Penelitinan ini selaras dengan penelitian Maximilianus Dasril Samu (2019), mengatakan bahwa dari akses media internet yang digunakan remaja terdapat 55 remaja memiliki 4-6 akun media sosial, dengan aplikasi terbanyak WhatsApp sebesar 55,0\% dengan menggunakan smartphone. Paparan informasi seharusnya meningkatkan pengetahuan dan pemahaman yang benar pada remaja, khusus nya tentang kesehatan reproduksi dan seksual.Hal ini sejalan dengan teori Pangestitika (2018) yang mengatakan bahwa dampak positif dari media sosial WhatApp yaitu pertukaran informasi menjadi cepat dan mudah, WhatsApp juga dapat dimanfaatkan untuk mempermuda siswa dalam mengirimkan tugas, Aplikasi WhatsApp selain dalam kegiatan belajar dapat di gunakan oleh guru, pihak sekolah dan wali murid, Pihak sekolah dapat melakukan komunikasi dengan wali murid melalui fitur WhatsApp seperti pengiriman foto, video, dan lainlainya sehinga wali murid dapat memonitor aktivitas siswa di sekolah dan dapat memperoleh informasi lainya seperti pengumuman atau informasi penting lainya melalui komonikasi dengan guru atau pihak sekolah. Penilitian ini sejalan dengan penilitian Muhamad Wildan Sahidillah (2019), mengatakan penggunaan WhatsApp sebagai media leterasi digital siswa yaitu siswa dapat berbagi materi pelajaran WhatsApp memiliki fitur yang bisa menyimpan dokumen dalam bentuk $P D F$, microsoft word, excel, powerpoint, maka dari itu pengunaan WhatsApp dapat berbagi dukemen dengan puasa dan jauh lebih muda. Selain itu bisa digunakan sebagai pembelajaran jarak jauh (PJJ) mengunakan fitur voice note.

Pembelajaran jarak jauh bisa digunakan oleh siswa dengan guru yang tergabung dalam satu grup tertentu. Pembelajar bisa dilakukan sesuai kesepakatan guruh dan siswa. WhatsApp bisa digunakan untuk membagikan materi melalui status, siswa mengunakan aplikasi WhatsApp story atau status di WhatsApp siswa bisa berbagi, vedeo dan link mengunkan status.

Tabel 4 Distribusi Frekeunsi Responden Beadasarkan Perilaku Seksual Berisiko Pada Remaja SMKN X Jakarta Timur Tahun 2020 $(\mathrm{N}=104)$

\begin{tabular}{ccc}
\hline Variabel & Frekuensi & Presentasi \\
\hline Beriko & 58 & $55,8 \%$ \\
Tidak & 46 & $44,2 \%$ \\
Berisiko & & \\
\hline Total & 104 & $100 \%$ \\
\hline
\end{tabular}


Tabel 4 hasil analisis didapatkan bahwa perilaku seksual beresiko pada remaja mayoritas perilaku seksual beresiko sebanyak 58 responden $(55,8 \%)$ sedangkan perilaku seksual tidak beresiko pada remaja hanya 46 responden $(44,2 \%)$.

Dalam penelitian ini didapatkan hasil bahwa reponden yang melakukan perilaku seksual berisiko yaitu reponden yang menyatakan berimajinasi tentang perilaku seksual setelah mendapatkan link video porno dari WhatsApp sebanyak, responden pernah terangsang saat melihat video atau gambar pornografi sebelum melakukan hubugan seksual, senang berjalan sambil berpegangan tangan dengan lawan jenis, berpelukan dengan lawan jenis, mencium kening, berciuman bibir dengan lawan jenis yang disukai, pernah disentuh atau menyentuh bagian tubuh sensitif (leher,dada paha,kemaluan) dengan pacar, yang mengajak atau diajak untuk melakukan hubungan seksual sebelum menikah, peranah dipaksa sama pasangan untuk melakukan hubungan seksual.

Hasil Penelitian ini selaras dengan penelitian yang diteliti Suwarni Linda (2015), bahwa tahapan perilaku seksual berisiko pada remaja dimulai dengan berpegangan tangan $(82,7 \%)$, berpelukan $(60,7 \%)$, ciuman bibir $(47,7 \%)$, meraba daerah sensitif sendiri $(19,3 \%)$, seks oral $(7 \%)$, seks anal (4\%), intercourse $(14,7 \%)$. Diantara remaja yang melakukan intercourse, $3,3 \%$ pernah mengalami kehamilan yang tidak diinginkan (KTD).Penelitian ini sejalan dengan Survei Kesehatan Reproduksi Remaja Indonesia (SKRRI) (2011), remaja yang berusia 14-19 tahun yang sudah melakukan perilaku seksual berisiko remaja di jabotabek menunjukkan dari 19.173 remaja sudah pernah berpacaran sebanyak $92 \%$, pada saat berpacaran melakukan pegangan tangan sebanyak $82 \%$, ciuman sebanyak $62 \%$, melakukan sebanyak petting, 10,2\%.

Penilitian ini didukung oleh teori dari Sarwono (2010) Jenis-jenis perilaku seksual berisiko yang sering dilakukan oleh remaja yaitu kissing ciuman yang dilakukan untuk menimbulkan rangsangan seksual, Necking berciuman di sekitar leher bawah, petting perilaku menggesek-gesekan bagian tubuh yang sensitif sepeti payudara dan organ kelamin, intercouse bersentuan dua organ secara seksual yang dilakukan oleh remaja pria dan wanita, melihat gambar video pornografi gambaran yang dirancang dengan sengaja dan semata-mata untuk membangkitkan nafsu seks.Hasil penelitian ini sesuai dengan penelitian yang diteliti oleh (Mahmud dkk, 2016)menyatakan bahwa perilaku seksual berisiko lebih tinggi pada remaja yang mendapatkan paparan pornografi tinggi dengan sumber informasi seksual $(35,5 \%)$ dibandingkan dengan remaja yang mendapatkan paparan rendah dengan sumber informasi seksual $(17,3 \%)$.

Penelitian ini diperkuat oleh penilitian Edelina Angwarmase, (2016) didapatkan menunjukan bahwa sebagian besar mengalami paparan media berisiko tinggi yaitu 46 orang $(64,8 \%)$ dan kategori remaja yang telah terkena paparan media berisiko tinggi, seluruhnya telah melakukan perilaku seksual berisiko tinggi yaitu sebanyak orang 46 orang $(64,8 \%)$.Penelitian ini juga sejalan dengan penelitian Faridah (2018), pada responden yang berjenis kelamin laki-laki sudah melakukan perilaku seksual berisiko sebanyak 93,8\% sudah melakukan pegangan tangan, 64,8\% berciuman bibir sebanyak $64,8 \%$, meraba bagian payudara dan paha, $43 \%$, meraba atau diraba bagian alat kelamin di luar baju 37,5\%, meraba atau diraba bagian alat kelamin sebanyak $33,6 \%$, pernah melakukan seks oral sebanyak $24,2 \%$, melakukan hubungan seksual sebelum menikah sebanyak 30,5\%.

Data tersebut diperkuat oleh BKKBN (2010), yang mengungkapkan bahwa dari 100 remaja di Jabotabek 51\% remaja sudah pernah melakukan hubungan seksual brisiko pranikah. Di Surabaya 54\%, Bandung 47\%, Medan 52\%, Yogya 37\%. 
Penelitian ini didukung oleh penelitan yang diteliti Mahmud dkk (2016), didapatkan responden yang berperilaku seksual berisiko $(20,9 \%)$ dan $5,1 \%$ diantaranya mengaku pernah melakukan hubungan seksual. Alasan terbanyak yang dikemukakan remaja adalah karena ingin tahu/coba-coba (50\%). Responden mengaku melakukan hubungan seksual dengan pacarnya sebanyak $(87,5 \%)$ dan tempat melakukannya di hotel/ wisma (50\%).

Penilitian ini sejalan dengan survey yang dilakukan Greater Jakarta Transition to Adulthood survey (GTAS), (2011) mengatakan bahwah pada remaja di daerah Jakarta, Bekasi dan Tangerang didapatkan hasil bahwa sebanyak $11 \%$ dari remaja yang belum menikah pernah melakukan hubungan seks, dengan perbadingan $16 \%$ pada laki laki dan 5\% pada perempuan.

Berdasarkan data penelitian Reni Dwi Parihat (2015), mengatakan remaja yang berkontak fisik pegangan tangan, memeluk, mencium pipi sebanyak 58,3\%, mencium bibir sebanyak $22,4 \%$, memegang payudara kekasih sebanyak 8,4\%, memegang alat kelamin kekasih dengan tangan sebanyak 5,8\%, mengelus kelamin kekasi hingga terangsang $5,6 \%$, pernah bersetubuh sebanyak 2,8\%, jumlah pasangan yang melakukan hubungan suami istri dengan keksih sebanyak 42,4\%.Penelitian diatas selaras dengan penelitian Risza Choirunissa (2016), bahwa didapatkan hasil penelitian yaitu perilaku seksual remaja yang beresiko dengan hasil tertinggi sebanyak 88 responden dan perilaku seksual pada remaja yang tidak beresiko sebanyak 66 responde.

Menurut penelitian yang dilakukan oleh Irwan (2017), bahwa perilaku seksual tidak berisiko pada remaja dapat berupa perilaku berpacaran sehat sebanyak 111 responden (53\%), adapun perilaku berpacaran sehat terdiri dari sehat secara fisik, psikis dan sosial. Pacaran sehat bisa berdampak positif pada remaja yaitu, prestasi akan meningkat prestasi belajar salah satu dampak positif pacaran yang sering di sebut sebut kaum muda. pacaran dapat meningkatkan prestasi. Hal tersebut bisa terjadi karena para kaum muda akan termotivasi oleh pasangannya sehingga dapat meningkatkan prestasi karena saat pacaran kaum muda bisa belajar bersama dan saling mengajari satu sama lain. Menurut Hakiim Lukman (2014), dampak positif pacaran prestasi belajar bisa meningkat, pergaulan bisa tambah meluas, mengisi waktu luang, perasaan aman, tenang, nyaman dan terlindung, tambah dewasa, menghindari stres, proses perkenalan, pacaran dapat mengenali pasangan pilihannya

Tabel 5 Hubungaan Pengunaan Media Sosial WhatsApp Berkonten Pornografi Dengan Perilaku Seksual Berisiko Remaja Di SMKN X Jakarta Timur 2020 ( $N=104)$

\begin{tabular}{|c|c|c|c|c|}
\hline \multirow{2}{*}{$\begin{array}{c}\text { Media } \\
\text { Sorigl } \\
\text { Whatsiong }\end{array}$} & \multicolumn{2}{|c|}{ Perilaku Selkual } & \multirow{2}{*}{$\begin{array}{c}\text { OR } \\
(95 \% \mathrm{CI})\end{array}$} & \multirow[t]{2}{*}{ P.value } \\
\hline & Iidalk Berisilata & Berisiko & & \\
\hline & Exelanensi $\quad \%$ & Erelkenensi y & & \\
\hline Posatif & $24,0 \%$ & $20,2 \%$ & 2,470 & 0,040 \\
\hline Negatif & $16,3 \%$ & $39,4 \%$ & & \\
\hline Jumlah & $100 \%$ & $100 \%$ & & \\
\hline
\end{tabular}

Berdasarkan hasil analisis dari Tabel 5 didapatkan sebanyak $38(39,4 \%)$ responden yang menggunakan media sosial WhatsApp negatif berkonten pornografi melakukan perilaku seksual berisiko. Sedangkan responden yang menggunakan media sosial WhatsApp positif sebanyak $20 \quad(20,2 \%)$ responden menunjukkan perilaku seksual tidak berisiko. Berdasarkan hasil uji statistik di dapatkan nilai $p$-value sebesar 0,040 artinya $p$-value $<0,05$, sehingga dapat disimpulkan bahwa H0 ditolak yang bermakna terdapat hubungan bermakna antara penggunaan media sosial WhatsApp berkonten pornografidengan perilaku seksual berisiko remaja di SMKN X Jakarta 
Timur serta didapatkan nilai $\mathrm{OR}=2,470$ yang informasi dan peran keluarga terhadap menunjukan bahwa apabila pengunaan media perilaku seksual pada siswa smk negeri 1 sosial WhatsApp berkonten pornografi kendari tahun 2016. Hasil penelitiannya negatif maka remaja memiliki kesempatan menunjukan bahwa akses media informasi untuk berperilaku seksual berisiko. Hal mempunyai hubungan dengan perilaku tersebut dapat terjadi karena pada masa seksual remaja siswa SMK Negeri 1 Kendari remaja terjadi perubahan fisik dan seksual kota kendari Tahun 2016 dengan nilai yang signifikan sehingga ketertarikan seksual $\mathrm{p}=0,010(0,05)$. Penilitian ini selaras dengan terhadap lawan jenis cukup besar dan penelitian Rismawan (2014), didapatkan dorongan seksual juga berkembang. hasil bahwa ada hubungan yang signifikan Perubahan fisik yang pesat dan perubahan antara keterpaparan pornografi menurut isi hormonal merupakan pemicu masalah (content) yang terdiri dari: gambar porno, kesehatan remaja karena timbulnya dorongan video/film porno, cerita porno yaitu motivasi seksual yang menjadikan remaja persentase tertinggi pada video/film porno rawan terhadap penyakit dan masalah sebesar $(69,90 \%)$, dengan pengetahuan kesehatan reproduksi, hubungan seks tentang perilaku seksual dengan $p$ pranikah (Kusmiran, 2014). value $=0,000$. Uji chi-square menunjukkan Hasil penelitian ini diperkuat oleh bahwa ada hubungan yang signifikan antara Maximilianus Dasril Samu (2019), dalam keterpaparan pornografi menurut isi (content) peniitiannya yang berjudul analisis pengaruh yang terdiri dari: internet, tablet, handphone, media internet terhadap perilaku yaitu persentase tertinggi pada internet penyimpangan seksual berisiko pada remaja sebesar $(42,22 \%)$, dengan tindakan tentang di smp negeri 4 tebing tinggi . didapatkan perilaku seksual dengan $p$ value $=0,023$, dan hasil uji chi square diperoleh nilai $p$-vule ada hubungan yang signifikan antara tingkat 0,015 yang artinya terdapat hubungan keterpaparan pornografi.

signitifikan pengaruh media intenet terhadap Penilitian ini didukung oleh penilitian perilaku penyimpangan seksual berisiko Dewi (2020), didapatkan hasil uji statistik remaja di SMP Negeri 4 Tebing Tinggi. diperoleh nilai $\mathrm{P}=0,000$ dan $\alpha 0,05$ nilai $\mathrm{p}$ ketika responden sering mengkses media lebih kecil dari $\alpha$, maka hipotesis Ho ditolak internet, maka responden tersebut berpeluang $\mathrm{Ha}$ diterima dapat disimpulkan ada 6,86 kali terjadi perilaku penyimpangan hubungan antara proporsi kejadian perilaku seksual berisiko.

remaja menggunakan smartphone secara

Hasil penelitian ini selaras dengan positif dan negatif ada hubungan yang Penilitian ini diperkuat oleh penilitian signifikan antara penggunaan smartphone Edelina Angwarmase, (2016) didapatkan dengan perilaku seksual pada remaja di hasil penelitian bahwa ada hubungan yang SMKNX.

kuat antara paparan media pornografi dengan perilaku seksual pada remaja dengan nilai $\mathrm{p}$ $=0,000<\alpha=0,05$ dan $r=0,769$. Penilitian ini selaras dengan peneliti Inah (2014), didapatkan hasil uji statisticterdapat korelasi yang signifikan ( $p$ value $0,000<0,05$ ), terdapat hubugan yang antara media sosial dengan perilaku seksual pranikah pada remaja di SMKN X.

Penelitian ini selaras dengan penilitian Andriani, Harni, dkk (2016), yang berjudul hubungan pengetahuan, akses media

\section{SIMPULAN}

Dari 104 siswa/sisiwi sebagian besar responden pada penelitian ini responden yang berusia 17 tahun lebih banyak $73(70,2 \%)$ dan responden yang berusia 16 tahun sebanyak $27(26,0 \%)$, dan responden yang berusia 18 tahun sebanyak 5 responden $(4,8 \%)$. Sebagian besar responden pada penelitian ini berjenis kelamin laki-laki lebih banyak yaitu 75 responden $(72,1 \%)$ dan responden yang berjenis kelamin perempuan sebanyak 29 responden $(27,9 \%)$. Sebagian 
besar reponden mengunakan media sosial WhatsApp secara postif sebanyak 46 responden $(44,2 \%)$ dan responden yang mengunakan media sosial WhatsApp secara negatif berkonten pornografi sebanyak 58 responden $(55,8 \%)$. Sebagian besar responden yang melakukan perilaku seksual berisiko sebanyak 58 responden $(55,8 \%)$ sedangkan perilaku seksual tidak berisiko hanya 46 responden $(44,2 \%)$. Hasil uji statistik chi square didapatkan nilai $p$-value sebesar0,040 <0,05 dapat disimpulkan bahwa terdapat hubungan bermakna (signifikan) antara penggunaan media sosial WhatsApp berkonten pornografi terhadap perilaku seksual berisiko pada remaja serta didapatkan nilai $\mathrm{OR}=2,470$ yang menunjukan bahwa apabila pengunaan media sosial WhatsApp negatif berkonten pornografi maka remaja memiliki kesempatan untuk berperilaku seksual berisiko.

\section{SARAN}

Hasil penelitian ini diharapkan dapat menjadi acuan penelitian selanjutnya untuk mencari variabel baru yaitu dorongan teman sebaya dalam mengakses konten pornografi yang bisa mempengaruhi pengunaan WhatsApp negatif sehinga berdampak buruk pada remaja untuk melakuka perilaku seksual berisiko. Kepada orangtua yang memiliki anak usia remaja agar lebih memberikan perhatian terkait penggunaan media sosial dan kepada remaja itu sendiri agar lebih cerdas dalam penggunaan media sosial khususnya WhatsApp.

\section{UCAPAN TERIMAKASIH}

Ucapan terimakasih kepada Dosen, Responden dan Keluarga dan sahabat yang telah membantu dan mendukung dalam penelitian ini

\section{DAFTAR PUSTAKA}

(BKKBN, 2013) Perilaku seksual berisiko remaja. Jakarta.

(GTAS)), G. J. T. to A. survey. (2011). survey remaja yang melakukan seks.

Akbar, N. I. (2017). Adiksi pornografi pada perilaku penyimpangan seksual anak. (studi kasus: empat kasus penyimpangan seksual anak yang ditangani oleh komnas anak). Skripsi: Program Studi Sosiologi, Universitas Negeri Jakarta.

Asosiasi Penyelenggara Jasa Internet Indonesia (APJII). (2018). Penggunaan internet di indonesia. Jakarta.

Azmiah Soebagijo. (2010). Pornografi di larang tapi di cari (G. Isani, Ed.). Jakrata.

BKKBN. (2017). Kesehatan reproduksi remaja. Retrieved from http://sdki.bkkbn.go.id/?lang=id

Dewi, Rostiana, M. (2020). Hubungan penggunaan smartphone dengan perilaku seksual bebas pada remaja di smk x gunung putri bogor. Jurnal Kesehatan Kusuma Husada.

Edelina Angwarmase. (2016). Paparan media hubungan dengan perilaku seksual pada remaja. Nursing News, Volume 1.

Faridah. (2018). Hubungan pengetahuan status sosial ekonomi, pola asuh orang tua, paparan media pornografi dengan perilaku seksual berisiko remaja. Program Studi Kebidanan Karawang, Poltekkes Kemenkes Bandung.

Hakiim Lukman. (2014). Fenomena Pacaran Dunia Remaja. Pekan BaruRiau: Zanafa Publishing.

Hootsuite. (2019). Jumlah penggunaan whatsApp di indonesia. Jakrata.

Inah. (2014). Hubungan antara peran media sosial dan peran orangtua dengan perilaku seks berisiko pranikah pada remaja kelas Xii di Smkn X. Stikes Muhamdiya Program Serjana Keperawatan.

Indriyani. (2014). Buku ajar keperawatan maternitas: upaya promotif dan preventif dalam menurunkan angka kematian ibu dan bayi. Yogyakarta: 
Ar-Ruzz Media.

irwan. (2017). Pacaran sehat perlikau tidak berisuko pada remaja. Jurnal Profesi Medika.

Jonathan, M. (2018). Panduan tentang seks orangtua membicarakan seks dengan anak. Jakarta: Gunung mulia.

Kemenkes RI. (2015). Sexual health reproductiv; situasi kesehatan reproduksi remaja. In Pusat Data dan Informasi Kementerian Kesehatan RI.

Komisi Perlindungan Anak Indonesia (KPAI). (2018). Kasus pornografi \& kejahatan online.

Kusmiran, E. (2014). Kesehatan Reproduksi Remaja dan Wanita. Jakarta Selatan: Salemba Medika.

Mahmud dkk. (2016). Faktor-faktor yang berhubungan dengan perilaku seksual remaja di kota padang. Jurnal Kesehatan Andalas.

Maximilianus Dasril Samura, C. S. (2019). Analisis pengaruh media internet terhadap perilaku penyimpangan seksual pada remaja di Smp Negeri 4 tebing tinggi. Jurnal Penilitian Kebidanan \& Kespro.

Muhamad Wildan Sahidillah. (2019). WhatsApp sebagai media literasi digital siswa. Varial Pendidikan, 13.

Nasrullah, R. (2017). Media sosial perspektif komunikasi, budaya, dan sosioteknologi. Bandung: Simbiosa Rekatama Media.

Word Health Organization(WHO). (2011). Seksual bebas pada remaja.

Pernita Hestin Untari. (2020). Jumlah penggunaan media sosial whatsApp. Retrieved from WhatsApp pada gadget mereka.

Pujiati Eny. (2018). Pengaruh paparan media pornografi dan teman sebaya terhadap perilaku seks remaja kabupaten kudus. Profesi Keperwatatan Akademik Keperawatan Krida Husada Kudus.

Rahmawati. (2012). Hubungan antara kecenderugan perilaku mengakses situs porno dan religiusitas pada remaja. Jurnal Stikes.

Reni Dwi Parihat. (2015). Perilaku berisiko dan faktor kejadian seks pranikah pada siswa/siswa sma sederajat di kota tangerang selatan.

Sarwono. (2010). Pisikologi remaja. Jakarta: Raja Grafindo Persada.

Sri Pujiati. (2016). Gambaran perilaku pacaran di pondok pesanten putri semarang. Jurnal Unimas.Ac.Id.

Survei Kesehatan Reproduksi Remaja Indonesia (SKRRI). (2011). Hasil survey kesehatan reproduksi remaja. Jakarta.

Suwarni Linda, S. (2015). Inisiasi seks pranikah remaja dan faktor yang mempengaruhi. Kesehatan Masyarakat.

Tri Wanda Rismawan. (2014). Hubungan antara keterpaparan pornografi dengan perilaku seksual remaja SMAN (Studi pada pelajar SMA Negeri di Kabupaten Jember).

We are Social \& Hootsuite. (2019). Jumlah Penggunaan Internet.

Yudrik Jahaja. (2011). Pisikologi Perkembangan Remaja. Jakarta: Kharisma Putra Utama.

Yuli, F. (2013). Hubungan pengetahuan status sosial ekonomi, pola asuh orang tua, paparan media pornografi dengan perilaku seksual remaja. 